\title{
PARP1 Gene Mutation
}

National Cancer Institute

\section{Source}

National Cancer Institute. PARP1 Gene Mutation. NCI Thesaurus. Code C154144.

A change in the nucleotide sequence of the PARP1 gene. 